\title{
MENINGKATKAN KEGIATAN EKSPLORASI ANAK MELALUI MEDIA LINGKUNGAN SEKITAR DI KELOMPOK B HOME SCHOOLING AL GIFARI KOTA KENDARI
}

\author{
Salmiati \\ Jurusan PG-PAUD, Universitas Halu Oleo.Jln. H.E.A Mokodompit, Kendari 93232, Indonesia. \\ E-mail:salmiati.salmi1994@yahoo.com, Telp: 085340419894
}

\begin{abstract}
Abstrak
Tujuan pelaksanaan penelitian ini adalah untuk meningkatkan kemampuan eksplorasi anak melalui media lingkungan sekitar di kelompok B Home Schooling Al-Gifari Kota Kendari. Subjek dalam penelitian ini adalah anak Kelompok B TK Al-gifari Kendari yang berjumlah 13 orang. Jenis penelitian ini adalah penelitian tindakan kelas (PTK) dan dilaksanakan 2 (dua) siklus, setiap siklus terdiri atas: perencanaan, pelaksanaan, observasi/evaluasi dan refleksi. Hasil observasi aktivitas mengajar guru pada siklus I tercapai $76 \%$, sedangkan hasil aktivitas belajar anak didik pada siklus I tercapai 53,48\%. Aktivitas mengajar guru mengalami peningkatan pada siklus II mencapai $84,61 \%$, dan aktivitas belajar anak didik juga mengalami peningkatan pada siklus II yaitu mencapai $92,30 \%$. Nilai untuk indikator hasil belajar anak baik secara individual maupun klasikal dikatakan berhasil apabila memperoleh $\geq 75 \%$ kategori BSB atau BSH. Hasil penelitian, kegiatan ekplorasi anak pada siklus I yaitu mencapai 53,48\% dan pada siklus II mengalami peningkatan mencapai 84,61\%. Dengan demikian dapat disimpulkan bahwa kegiatan ekplorasi pada anak dapat ditingkatkan melalui media lingkungan sekitar pada Kelompok B Home Schooling Al Gifari Kota Kendari.
\end{abstract}

Kata Kunci: Kegiatan Ekplorasi, Media Lingkungan Sekitar, Home Schooling

\section{IMPROVING CHILDREN'S EXPLORATION ACTIVITIES THROUGH THE MEDIA ENVIRONMENT IN GROUP B HOME SCHOOLING AL GIFARI \\ KENDARI}

\begin{abstract}
The purpose of this research is to improve the exploration ability of children through environmental media in the group B Home Schooling Al-Gifari Kendari. The subjects in this study are children of Group B TK Al-gifari Kendari which amounted to 13 people. This type of research is a classroom action research (PTK) and implemented 2 (two) cycles, each cycle consisting of: planning, implementation, observation / evaluation and reflection. Observation result of teacher teaching activity in cycle I reached 76, 92\% while result of learning activity of student in cycle I reached $53,48 \%$. Teacher teaching activity increased in cycle II reach 84,61\%, and learning activity of student also experience improvement in cycle II that reach 92,30\% value for indicator result of learning of child either individually or classical is said to succeed if get $\geq 75 \%$ BSB or BSH category. Result of research, activity of child exploration in cycle I that reach 53,48\% and in cycle II experience increase reach $84,61 \%$. Thus it can be concluded that the exploration activities in children can be improved through the surrounding environmental media in Group B Home Schooling Al Gifari Kendari.
\end{abstract}

Keyword: Exploration Activities, Media Environment, Home Schooling

\section{PENDAHULUAN}

PAUD sebagai pendidikan yang diselenggarakan sebelum jenjang pendidikan dasar, memiliki kelompok sasaran anak usia 0-6 tahun yang sering disebut masa emas perkembangan. Di samping itu, pada usia ini ank-anak masih sangat rentang yang apabila penanganannya tidak tepat justru dapat merugikan anak itu sendiri. Oleh karena itu, penyelenggaraan PAUD harus memperhatikan dan sesuai tahap-tahap perkembangan anak. 
Undang-undang Nomor 20 Tahun 2003 tentang Sistem Pendidikan Nasional pada Pasal 1 butir 14, pendidikan anak usia dini didefinisikan sebagai suatu upaya pembinaan yang ditujukan kepada anak sejak lahir sampai dengan usia enam tahun yang dilakukan melalui pemberian rangsangan pendidikan untuk membantu pertumbuhan dan perkembangan jasmani dan rohani agar anak memiliki kesiapan dalam memasuki pendidikan lebih lanjut.

Salah satu bentuk PAUD yaitu Home Schooling merupakan salah satu lembaga tempat pendidikan anak usia dini yang berada pada jalur formal, dimana pada usia ini merupakan masa keemasan (golden age) khususnya usia 5-6 tahun atau setara dengan Taman Kanak-Kanak. Home Schooling bertujuan membantu mengembangkan potensi yang dimiliki oleh anak antara lain nilai-nilai agama dan moral, social emosional, fisik motorik, kognitif, bahasa, dan seni. Maka dari itu pengembangan potensi yang dimiliki oleh anak tersebut hendaknya dilaksanakan dengan berbagai metode kegiatan belajar yang kreatif dan menyenangkan bagi anak didik.

Tylor dalam Masitoh dkk, (2007: 18) kegiatan eksplorasi memungkinkan anak untuk mengembangkan penyelidikan langsung melalui langkah-langkah spontan, belajar membuat keputusan tentang apa yang dilakukan, bagaimana cara melakukannya dan kapan melakukannya.

Aktivitas bereksplorasi ini merupakan kegiatan yang tidak membosankan bagi anak. Pasalnya melalui kegiatan ini anak akan mengenal banyak hal dan pengalaman baru yang tidak akan pernah anak dapatkan di dalam rumah. Selain itu kegiatan ini juga akan sekaligus melatih kreativitasnya. Memberikan ruang pada anak untuk bereksplorasi dapat merangsang kecerdasan otak anak.

Rachmawati \& Kurniati (2012: 15) berpendapat bahwa "Eksplorasi merupakan kegiatan penjelajahan yang dilakukananak terhadap sesuatu dan memberikan kesempatan anak untuk melihat, memahami, merasakan, dan pada akhirnya anak membuat sesuatu yang menarik perhatiannya". Dalam kehidupannya sehari-hari anak-anak banyak melakukan eksplorasi terhadap lingkungannya baik dengan benda, binatang, tanaman, manusia, peristiwa atau kejadian. Biarkan anak memanfaatkan benda-benda yang ada di sekitarnya dan biarkan anak melakukan trial dan error, karena memang anak adalah seorang penjelajah yang ulung.

Kegiatan eksplorasi anak melalui media dapat melatih anak menggunakan panca inderanya untuk mengenal berbagai gejala benda dan peristiwa (Slamet 2008: 75). Untuk menunjang terjadinya proses tersebut, guru harus menyiapkan metode yang tepat dalam pembelajaran. Anak usia dini membutuhkan metode yang dapat membuat mereka berinteraksi langsung dengan kegiatan yang dilakukan. Dalam hal ini guru dapat menggunakan metode eksplorasi lingkungan sekitar.

Pada masa anak usia dini, stimulasi yang paling baik diberikan kepada anak adalah kegiatan eksplorasi anak melalui media lingkungan sekitar. Karena eksplorasi merupakan langkah yang paling tepat bagi pembelajaran anak agar lebih cepat mempelajari, menguasai dan mempraktikan suatu materi pembelajaran yang disampaikan oleh pendidik atau setiap sisi kehidupan.

Berdasarkan hasil observasi awal di Home Schooling Al-Gifari menunjukan bahwa perkembangan sains sederhana anak sangat kurang, masih ada anak yang sulit melakukan kegiatan eksplorasi dan ada sebagian anak yang dapat melakukan kegiatan eksplorasi akan tetapi tidak mengetahui eksplorasi lingkungan sekitar. Serta disekolah sudah menggunakan media dalam pemgetahuan sains tetapi dalam penerapan media lingkungan sekitar masih terbatas untuk mengembangkan sains anak, dikala anak jenuh dalam proses pembelajaran tanpa menekankan pada pembelajaran sains seperti kegiatan eksplorasi pada anak. Meskipun demikian, berdasarkan pengamatan penulis bahwa potensi kegiatan eksplorasi anak masih sangat memiliki peluang potensial untuk dikembangkan secara optimal.

Data yang diperoleh dari hasil observasi awal yang dilakukan oleh peneliti pada bulan agustus 2017 dapat disimpulkan bahwa keterampilan proses eksplorasi dari 13 anak yang diobservasi terdapat 5 anak tergolong dalam kriteria cukup, 5 anak tergolong dalam kriteria kurang, dan 3 anak tergolong dalam kriteria kurang sekali. Penggolongan tersebut didasarkan pada instrumen penelitian yang telah dibuat oleh peneliti. Oleh karena itu, peneliti memiliki ide untuk menggunakan metode eksplorasi lingkungan sekitar dalam pembelajaran guna mengembangkan keterampilan proses sains anak. Penggunaan 
metode eksplorasi lingkungan sekitar diharapkan dapat menumbuhkan ketertarikan dan keaktifan anak dalam belajar, sehingga proses belajar mengajar yang dilakukan dapat memberikan pengalaman yang berkesan bagi anak dan hasil pembelajaran lebih optimal.

Berdasarkan permasalahan tersebut, maka peneliti berusaha merancang suatu media pembelajaran yang menarik dan menyenangkan bagi anak untuk meningkatkan kemampuan eksplorasi anak melalui media lingkungan sekitar. Media lingkungan sekitar yang dimaksudkan yaitu berbagai jenis buah-buahan yang akan di eksplor oleh anak dengan mengamati warnanya, menyebutkan warnanya, merasakan secara langsung buah tersebut, meraba permukaan buah, mengupas buah serta mengkomunikasikan kembali kegiatan yang telah dilakukan. Adapun buah-buah yang di gunakan yaitu pisang, jeruk, salak, anggur, papaya, apel.

Adanya media lingkungan sekitar, maka anak dapat berinteraksi langsung dengan kegiatan yang diberikan oleh guru dan membuat eksplorasi lingkungan sekitar terutama dalam bidang sains. Dengan begitu diharapkan anak dapat memahami proses dari kegiatan yang diberikan, mengerti konsep-konsep sains, dan tentunya mendukung kemampuan kognitif anak dalam keterampilan pembelajaran sains. Di samping itu penggunaan metode eksplorasi lingkungan sekitar juga memudahkan guru karena dapat menggunakan media yang ada di lingkungan sekitar.

Manfaat penggunaan media lingkungan sekitar adalah dapat berkesan dalam ingatan siswa, membangkitkan gairah dan semangat optimis dalam diri anak serta menumbuhkan rasa kebersamaan dan kesetiakawanan sosial yang tinggi serta dapat menghayati peristiwa yang berlangsumg dengan mudah, dan dapat memetik butir-butir hikmah yang terkandung di dalamnya dengan penghayatan anak sendiri.

\section{METODE}

Jenis penelitian ini termaksud dalam jenis Penelitian Tindakan Kelas (PTK) yang dilaksanakan pada semester genap tahun ajaran 2016/2017 pada TK Home Schooling Al-Gifari Kota Kendari. Waktu penelitian ini dilaksanakan pada tanggal 24 Agustus 2017 sampai dengan 19 September 2017 yang berjumlah 13 orang anak yaitu 10 orang anak laki-laki dan 3 orang anak perempuan.
Faktor yang akan diteliti dan diamati dalam penelitian ini yaitu (a) Faktor peserta didik kelompok B Home Schooling Al Gifari Kendari dalam melakukan aktivitas kegiatan belajar dan meningkatkan kegiatan Eksplorasi anak melalui media lingkungan sekitar, (b) Faktor Guru, mengamati aktivitas guru dan proses pembelajaran dalam upaya untuk melihat bagaimana upaya meningkatkan kegiatan Eksplorasi anak di kelompok B Home Schooling Al Gifari Kota Kendari, (c) Hasil belajar anak tentang kegiatan Eksplorasi anak dengan meng gunakan media lingkungan sekitar.

Prosedur penelitian tindakan kelas ini dibagi dalam dua siklus yaitu sesuai dengan rencana seperti apa yang telah didesain dan faktor yang diselidiki. Secara umum teknik penelitian di TK menggunakan tanda sebagai berikut: belum berkembang (BB), mulai berkembag (MB), berkembang sesuai harapan (BSH), berkembang sangat baik (BSB) (Depdiknas, 2004).

Data yang diperoleh dari penelitian ini adalah data kualitatif yang diperoleh melalui pedoman/lembar observasi aktivitas guru dan anak dalam pembelajaran kegiatan eksplorasi dengan media lingkungan sekitar. Dan data kuantitatif diperoleh melalui lembar instrument/evaluasi anak didik selama pembelajaran.

Teknik analisis data yang digunakan adalah dengan menggunakan analisis deskriptif. Metode analisis deskriptif adalah metode yang menjelaskan atau menggambarkan fenomena penelitian secara objektif. Analisis data adalah suatu cara menganalisis data selama peneliti mengadakan penelitian. Penelitian ini termaksud penelitian kualitatif menerangkan aktifitas anak dan guru yang diperoleh melalui observasi dan unjuk kerja secara penelitian berlangsung. Selain itu juga mengacu pada pedoman pemberian penilaian dalam satuan pendidikan di RA yaitu dengan penilaian secara kualitatif atau dengan memberikan nilai data bentuk symbol seperti: Belum Berkembang) BB). Mulai Berkembang (MB), Berkembang Sesuai Harapan (BSH), Berkembang Sangat Baik (BSB). (Depdiknas, 2004: 26).

Indikator keberhasilan dalam penelitian ini apabila 75\% dari jumlah anak kelompok B TK Home Schooling Al-Gifari Kota Kendari mencapai nilai Berkembang Sesuai Harapan (BSH) dan nilai Berkembang Sangat Baik (BSB) maka pelaksanaannya dikatakan berhasil dan tindakan siklus dihentikan. 


\section{HASIL DAN PEMBAHASAN}

Sebelum kegiatan penelitian akan dilaksanakan, peneliti terlebih dahulu melakukan pertemuan awal dengan kepala Home Schooling Al-Gifari Kota Kendari, yaitu pada tanggal 6 Agustus 2017. Pertemuan ini bermaksud untuk menyampaikan tujuan dari peneliti, yaitu mengadakan penelitian di Home Schooling Al-Gifari Kota Kendari. Selanjutnya, kepala Home Schooling Al-Gifari Kota Kendari mengarahkan peneliti untuk berdiskusi dengan guru kelompok $\mathrm{B}$ sekaligus sebagai observer/teman sejawat peneliti dalam pelaksanaan penelitian.

Wawancara singkat dilakukan peneliti dengan guru Kelompok B Home Schooling AlGifari Kota Kendari yaitu untuk mengetahui sejauh mana kemampuan eksplorasi anak dan apa saja kelemahan-kelemahan yang dialami anak selama proses pembelajaran berlangsung.

Berdasarkan observasi yang dilakukan, peneliti melihat bahwa kemampuan eksplorasi anak pada Kelompok B Home Schooling AlGifari Kota Kendari masih rendah dan perlu ada bimbingan dari guru yaitu berada pada taraf mulai berkembang ( $\left.\mathrm{MB}^{* *}\right)$.

Peneliti dan guru sepakat untuk menggunakan media lingkungan sekitar pada kegiatan pembelajaran untuk meningkatkan kemampuan eksplorasi anak, maka kegiatan selanjutnya peneliti menyiapkan beberapa hal yang diperlukan selama pelaksanaan tindakan. Dalam persiapan ini, peneliti berkolaborasi dengan guru kelompok B Home Schooling AlGifari Kota Kendari sebagai observer dalam penelitian ini.

Selanjutnya peneliti melakukan hal-hal sebagai berikut:(a) Menyusun Rencana Kegiatan Mingguan (RKM), (b) Menyusun Rencana Kegiatan Harian (RKH) serta langkah-langkah perbaikan, (b) Menyiapkan alat peraga yang diperlukan, (c) Membuat alat bantu pembelajaran, (d) Membuat lembar kerja anak, (e) Membuat alat evaluasi unjuk kerja anak.

Pelaksanan penelitian ini terdiri dari dua siklus, dimana setiap siklus terdiri dari empat kali pertemuan sesuai dengan prosedur penelitian yang sudah di rancang sebelumnya. Pada pelaksanan pembelajaran tiap pertemuan menggunakan media lingkungan sekitar sesuai dengan tema yaitu buah-buahan. Setiap pertemuan terdiri dari tiga tahapan kegiatan yaitu kegiatan awal, kegiatan inti, kegiatan akhir. Kegiatan awal, yaitu kegiatan pendahuluan yang dilakukan guru sebelum masuk pada tema pembelajaran yang diawali dengan salam dan membaca doa, memotivasi anak serta memberikan apresiasi yang berhubungan dengan tema pembelajaran.

Kegiatan inti yaitu guru menjelaskan tujuan pembelajaran yang berhubungan dengan lingkungan sekitar sesuai dengan tema, kemudian guru terlebih dahulu memberikan pertanyaan kepada anak tentang macam-macam buah, warna buah, anak di persilahkan untuk merasa atau mencicipi buah tersebut, meraba permukaan buah dan mengupas buah secara langsung.

Pada kegiatan akhir, guru melakukan tanya jawab tentang kegiatan yang telah dilaksanakan. Guru bertanya kepada anak tentang pelajaran yang telah dipelajari melalui penerapan media lingkungan sekitar, setelah itu menyanyikan lagu pulang sekolah dan mengucapkan doa pulang. Guru mengadakan refeksi kembali pada pembelajaran untuk meningkatkan kegiatan ekplorasi anak.

Pelaksanaan tindakan siklus I dilaksanakan di ruang Kelompok B Home Schooling Al-Gifari Kota Kendari, anak telah siap belajar dengan guru yaitu meningkatkan kemampuan eksplorasi anak melalui media lingkungan sekitar sesuai RKH (tema: kebutuhanku/makanan dan minuman), yaitu sebelum kegiatan pembelajaran dimulai, didahului dengan apel/berbaris yang dipimpin oleh guru. Pada saat berbaris, setelah barisan anak didik dianggap rapi dan tertib, anak didik menyanyikan beberapa lagu yang dipimpin oleh guru, kemudian mengucapkan salam dan mencium tangan ibu guru sebelum masuk kelas. Selanjutnya, setelah anak didik telah duduk dengan rapi, guru mengucapkan salamdan anak membalas salam kemudian sebelum belajar anak membaca doa.

Kegiatan inti dimulai dengan menginformasikan kegiatan yang akan dilakukan oleh anak. Kegiatan eksplorasilah yang akan dijadikan tindakan oleh peneliti. Guru mempersilakan anak untuk meperhatikan makanan sehat seperti mengamati ciri-ciri buah. Sebelum kegiatan dimulai guru memberikan petunjuk kepada anak tentang kegiatan yang mereka lakukan. Pada kegiatan eksplorasi guru terlebih dahulu memberikan pertanyaan kepada anak tentang macam-macam buah, warna buah, anak di persilahkan untuk merasa buah tersebut, meraba permukaan buah dan mengupas buah secara langsung dan mengajak anak melakukan 
prediksi warna apa yang ada pada buah tersebut. Hanya ada beberapa anak yang mencoba menjawab pertanyaan dari guru, sedangkan sebagian besar anak tidak menjawab karena masih bingung. Selanjutnya guru memberi kesempatan kepada anak untuk mencoba sendiri kegiatan-kegiatan tersebut.

Pada tahap ini guru memberi pujian kepada anak yang mampu mengerjakan seluruh kegiatan. Selanjutnya guru melakukan tanya jawab dan mengulas kegiatan yang dilakukan.. Dari tanya jawab tersebut dapat dilihat kemampuan anak dalam menyerap kegiatan mengeksplorsi lingkungan sekitar.

Pertemuan pertama tindakan siklus I dengan metode eksplorasi lingkungan sekitar berjalan dengan baik, meskipun pada awalnya banyak anak yang berebut memilih kegiatan tersebut. Sebelum menutup pembelajaran, guru mengajak anak menyanyikan lagu "sayo nara", " ayo makan buah". Kegiatan dilanjutkan dengan berdoa untuk pulang yang dipimpin oleh guru.

Berdasarkan hasil yang telah diperoleh pada pelaksanaan kegiatan untuk siklus I, terlihat bahwa kegiatan penelitian yang dilaksanakan belum terselesaikan sepenuhnya terutama dalam meningkatkan kemampuan eksplorasi anak melalui media lingkungan sekitar di kelompok B yang secara klasikal diperoleh nilai keberhasilan mencapai 65\%, sedangkan indikator kinerja yang ditetapkan minimal $75 \%$ anak memperoleh nilai berkembang sesuai harapan (BSH) dan berkembang sangat baik (BSB).

Berdasarkan hasil yang telah diperoleh pada pelaksanaan kegiatan untuk siklus I, maka terlihat bahwa kegiatan penelitian yang dilaksanakan belum terselesaikan terutama dalam meningkatkan meningkatkan kegiatan ekplorasi anak melalui media lingkungan sekitar pada kelompok B yang secara klasikal diperoleh nilai keberhasilan mencapai 70,8\%, sedangkan indikator keberhasilan yang harus dicapai $\geq 75 \%$ ataumencapai hasil konversi bobot nilai antara 2,50-4,00 atau Berkembang Sesuai Harapan (BSH) dan Berkembang Sangat Baik (BSB).

Hasil yang diperoleh tahap kegiatan penelitian tindakan silkus I dan hasil temuantemuan yang diperoleh, maka penelitian yang bekerja sama dengan guru kelompok B memiliki dan mendiskusikan kelemahan dan kekurangankekurangan yang terdapat pada pelaksanan tindakan siklus I, serta harus segera melaksanakan persiapan dan membuat perencanaan dengan matang, segala yang dilakukan pada tindakan silkus I harus dicermati dan diperbaiki kembali. Dari hasil obesrvasi, maka beberapa hal yang harus diberbaiki untuk pelaksanaan siklus II.

Mengacu pada data hasil temuan observasi, evaluasi dan refleksi pada tahap kegiatan silkus I, maka penelitian bersama guru kelompok B sepakat untuk melaksanakan kegian untuk tindakan siklus II dengan lebih optimal dan persiapan yang lebih baik lagi, agar kekurangan-kekurangan yang terdapat pada siklus I dapat diminimalisir dalam perencanaan tindakan ini peneliti kembali menyiapkan halhal yang akan dilakukan dalam pembelajaran, seperti: (1) membuat skenario pembelajaran berupa Rencana Perlengkapan Pembelajaran Harian (RPPH) dan Rencana Perlegkapan Pembelajan Mingguan (RPPM) untuk siklus II pada pertemuan I, pertemuan II, Pertemuan III dan Pertemuan IV, yang mengacu pada pembelajaran meningkatkan kegiatan ekplorasi anak melalui media lingkungan sekitar, (2) membuat lembar observasi aktivitas guru dalam proses pembelajaran sebagai acuan untuk melaihat keterlaksanan proses pembelajaran sesuai yang diracanakan, (3) membuat lembar observasi aktivitas anak didik selama proses pembelajaran melalui media lingkungan sekitar.

Pelaksanaan tindakan dilakukan oleh penelitian sedangkan guru kelompok B bertindak sebagai observer. Pelaksanaan pada tindakan siklus II dilakukan dalam 4 kali pertemuan, dimana proses pembelajaran dilakukan berdasarkan rencana pembelajaran yang telah dibuat pada tahap perencanan. Tindakan penelitian siklus II dilaksanakan di ruangan. Anak didik telah siap belajar dengan guru yaitu dengan meningkatkan kemampuan eksplorasi anak melalui media lingkungan sekitar yaitu buah-buahan. Setelah perencanaan awal yaitu pelaksanaan tindakan siklus II ini dilaksanakan sebanyak empat kali pertemuan, selanjutnya peneliti yang berkolaborasi dengan guru kelompok B untuk melaksanakan tindakan yang sudah direncanakan.

Pada pelaksanaan tindakan ini, peneliti melaksanakan skenario pembelajaran sesuai RKH (tema: kebutuhanku/ makanan dan minuman), yaitu sebelum kegiatan pembelajaran dimulai, didahului dengan apel/berbaris yang dipimpin oleh guru. Pada saat berbaris, setelah barisan anak didik rapi, dan tertib anak didik menyanyikan beberapa lagu yang dipimpin oleh guru, kemudian mengucapkan salam dan mencium tangan ibu guru sebelum masuk kelas. 
Selanjutnya, setelah anak didik telah duduk dengan rapi, guru mengucapkan salam dan anak membalas salam kemudian sebelum belajar anak membaca doa.

Kegiatan inti dimulai dengan menginformasikan kegiatan yang akan dilakukan oleh anak. Kegiatan eksplorasi inilah yang akan dijadikan tindakan oleh peneliti. Guru mempersilakan anak untuk meperhatikan makanan sehat seperti mengamati ciri-ciri buah. Sebelum kegiatan dimulai guru memberikan petunjuk kepada anak tentang kegiatan yang mereka lakukan. Pada kegiatan eksplorasi guru terlebih dahulu memberikan pertanyaan kepada anak tentang macam-macam buah, warna buah, anak di persilahkan untuk merasa buah tersebut, meraba permukaan buah dan mengupas buah secara langsung dan mengajak anak melakukan prediksi warna apa yang ada pada buah tersebut. Hanya ada beberapa anak yang mencoba menjawab pertanyaan dari guru, sedangkan sebagian besar anak tidak menjawab karena masih bingung. Selanjutnya guru memberi kesempatan kepada anak untuk mencoba sendiri kegiatan mengeksplorasi buah-buahan.

Kegiatan eksplorasi anak agar lebih mudah untuk dilakukan observasi. Awalnya banyak sekali anak yang ingin melakukan kegiatan mengupas buah, mencicipi rasa buah, namun guru memberi pengertian bahwa anak harus satu persatu maju di depan. Anak-anak sangat antusias untuk melakukan kegiatan tersebut karena mereka benar-benar melakukan sendiri, mengamati proses, dan melihat hasilnya.

Pada tahap ini guru memberi pujian kepada anak yang mampu mengerjakan seluruh kegiatan. Selanjutnya guru melakukan tanya jawab dan mengulas kegiatan yang dilakukan. Untuk kegiatan yang dilakukan guru mengevaluasi dengan memberikan pertanyaan kepada anak tentang mecam-macam buah yang dihasilkan, apa saja macam-macam buah. Dari evaluasi tersebut dapat dilihat kemampuan anak dalam menyerap kegiatan menyebutkan macammacam buah yang dilakukan dengan metode lingkungan sekitar.

Observasi dilakukan untuk melihat pelaksanaan pembelajaran dengan meningkatkan kegiatan ekplorasi anak melalui media lingkungan sekitar sesuai dengan rencana kegiatan harian yang telah dibuat. Observasi dilakukan oleh guru kelompok B Home Schooling Al Gifari yang bertindak sebagai kolaborator terhadap aktivitas guru sesuai dengan lembar observasi kegiatan mengajar guru yang telah dipersiapkan dengan menuliskan "ya" jika indikator yang diamati terlaksana dan "tidak" jika indicator yang diamati tidak terlaksana dan memberi cacatan komentar atau keterangan. Demikian pula untuk aktivitas belajar anak didik selama proses belajar mengajar berlangsung.

Jika dilihat dari hasil perhitungan nilai secara klasikal pada siklus II yaitu $84.61 \%$ anak didik telah mencapai indikator keberhasilan yang ditetapkan oleh peneliti yaitu $\geq 75 \%$. Dengan demikian penelitian ini telah berhasil dilaksanakan, maka peneliti dan guru kelompok B sepakat untuk tidak melanjutkan pada siklus berikutnya, dengan kata lain tindakan penelitian ini dihentikan.

Berdasarkan hasil refleksi tersebut kemudian di lakukan langkah-langkah perbaikan pada Siklus II sehingga memperoleh hasil yang cukup signifikan dimana hanya ada satu aspek yang tidak terpenuhi yaitu guru tidak meminta anak untuk bertanya tentang kegiatan yang telah diberikan.

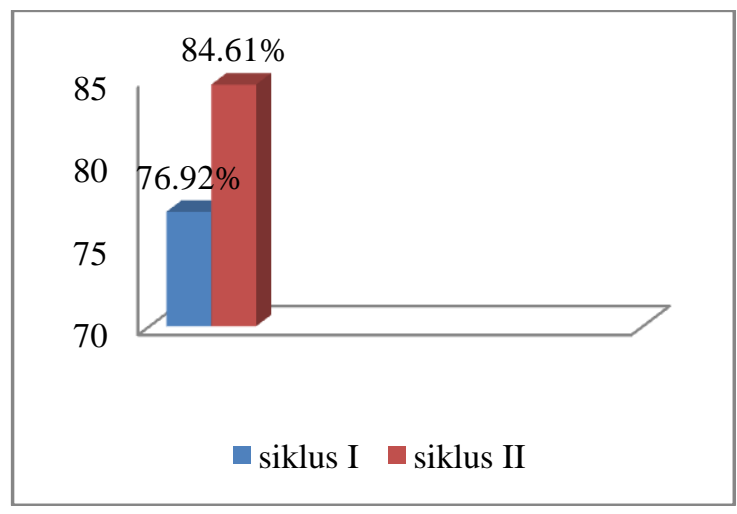

\section{Gambar 1. Histogram Hasil Analisis Aktivitas Mengajar Guru Siklus I dan II}

Berdasarkan diagram pada gambar 1 tersebut dapat diketahui bahwa aktivitas mengajar guru pada siklus I mencapai $76.93 \%$ dari 13 aspek yang diamati hanya 10 aspek yang 13 erlaksana, kemudian mengalami peningkatan pada siklus II sebesar 84,62\% dari 13 aspek yang tidak terlaksana hanya 2 aspek, dengan selisih yang diperoleh dari siklus I ke siklus II sebesar $15,38 \%$, dengan demikian hasil analisis aktivitas mengajar guru pada penelitian ini telah mencapai hasil yang maksimal.

Hasil analisis aktivitas belajar anak di sekolah sesuai dengan pedoman atau lembar aktivitas belajara anak didik sebanyak 13 aspek yang akan dicapai oleh anak. Pada siklus I skor ketuntasan yang di capai anak yaitu $76,93 \%$ atau 
yang tercapai hanya 10 aspek. Kemudian mengalami peningkatan pada siklus II sebesar $84,62 \%$ atau yang tercapai sebanyak 11 aspek.

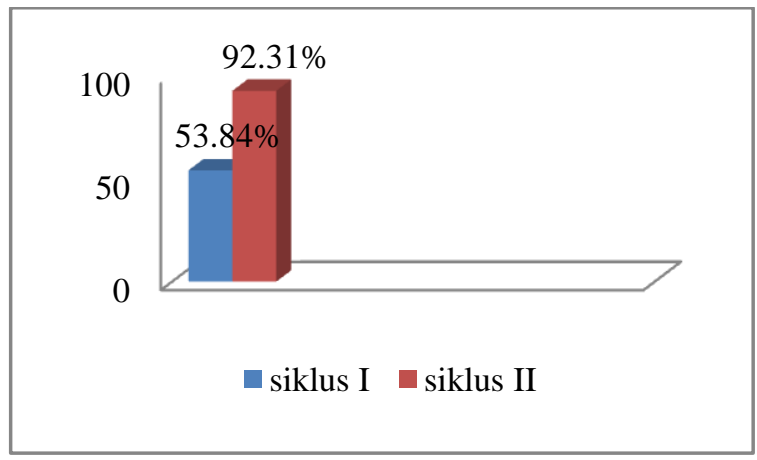

Gambar 2. Histogram Hasil Analisis Aktivitas Belajar Anak Siklus I dan II

Berdasarkan diagram gambar 2 tersebut dapat diketahui bahwa hasil analisis aktivitas belajar anak dalam meningkatkan kegiatan ekplorasi anak melalui media lingkungan sekitar pada siklus I mencapai $53,85 \%$ dan mengalami peningkatan sebesar $92,31 \%$ pada siklus II, dengan demikian maka hasil analisis aktivitas belajar anak dalam meningkatkan kegiatan ekplorasi anak melalui media lingkungan sekitar kelompok BHome Schooling Al GifariKendari telah mencapai hasil yang maksimal.

Hasil analisis yang diperoleh terhadap meningkatkan kegiatan ekplorasi anak melalui media lingkungan sekitar kelompok B Home Schooling Al Gifari Kendari, pada observasi awal jika dibandingkan dengan pelaksanaan siklus I terlihat adanya peningkatan namun belum mencapai indikator kinerja yang yang diharapkan, sehingga perlu dilaksanakan pada siklus II.

Pada observasi awal terlihat kegiatan ekplorasi anak masih kurang. Anak kurang berminat dalam mengikuti kegiatan ekplorasi media yang disediakan. Guru kurang optimal dalam menstimulasi ekplorasi anak di kelompok B Home Schooling Al Gifari Kendari. Hal tersebut, dikarenakan metode yang dilakukan oleh guru dalam menstimulasi ekplorasi anak terlalu monoton kurang bervariatif sehingga minat anak berkurang dan pesan pembelajaran tidak dapat diterima anak secara optimal. Peneliti bekerjasama dengan guru observer memberikan motivasi kepada anak didik baik lewat lagu anak maupun cerita yang dapat menjadikan anak untuk tertarik dalam melakukan aktivitas belajar mengikuti kegiatan ekplorasi anak siklus I kemudian guru melakukan perbaikan pada siklus II.

Setelah dilakukan perbaikan-perbaikan dalam siklus II, ternyata hasil yang diperoleh mengalami peningkatan yang cukup signifikan pada aspek peningkatan ekplorasi anak melalui media lingkungan sekitar. Berdasarkan data yang diperoleh pada siklus I dan siklus II. Untuk lebih jelasnya dapat dilihat pada gambar histogram berikut:

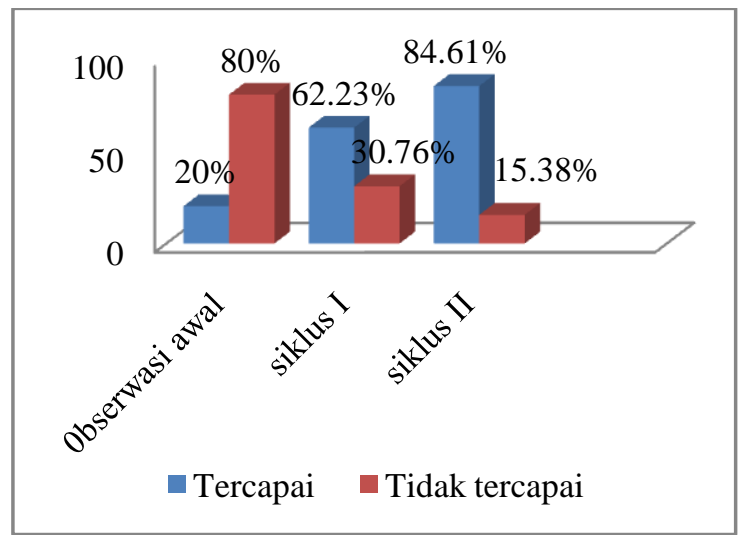

Gambar 3. Histogram Hasil Analisis Kegiatan Eksplorasi Anak

Selama kegiatan penelitian berlangsung, data hasil temuan yang diperoleh sebagaimana dideskripsikan pada halaman sebelumnya, dapat diasumsikan bahwa kegiatan pembelajaran dalam meningkatkan kegiatan ekplorasi anak melalui media lingkugan sekitar yang dirancang, disusun dan dilaksanakan secara baik dan optimal oleh peneliti yang bekerjasama dengan guru Kelompok B pada setiap pertemuan siklus I dan siklus II sangat memberikan manfaat pada anak dengan pengalaman langsung, serta ekplorasi anak menunjukkan peningkatan. Jika dilihat dari pemahaman anak mulai dari pelaksanaan siklus I sebesar 62,32\% jika dibandingkan pada tahapan observasi awal penelitian yang hanya mencapai $20 \%$ dan pada tindakan siklus II mencapai persentase sebesar $92,30 \%$, menunjukkan hasil yang lebih baik dari sebelumnya, karena indikator kinerja yang ditetapkan telah tercapai yaitu $\geq 75 \%$ maka penelitian ini dapat dihentikan.

\section{SIMPULAN DAN SARAN}

\section{Simpulan}

Berdasarkan hasil penelitian dan pembahasan pada siklus I dan siklus II, maka dapat disimpulkan: melalui aktivitas mengajar guru dalam menggunakan media lingkungan 
sekitarpada siklus I tercapai 69,23\%. Hasil evaluasi meningkatkan kegiatan ekplorasi anak pada siklus I tercapai $69,23 \%$ atau 8 orang dari 13 orang anak yang mengikuti pembelajaran. Aktivitas mengajar guru dengan meningkatkan kegiatan ekplorasi anak melalui media lingkungan sekitar pada siklus II tercapai $84,61 \%$. Hasil evaluasi kegiatan ekplorasi anak pada siklus II tercapai $84,61 \%$ atau 11 orang dari 13 orang anak yang mengikuti pembelajaran. Dengan demikian, maka kegiatan ekplorasi anak Kelompok B Home Schooling Ali Gifari Kendari dapat ditingkatkan melalui penggunaan media lingkungan sekitar.

\section{Saran}

Berdasarkan kesimpulan tersebut, maka peneliti menyarankan hal-hal sebagai berikut: (a) Bagi guru, dalam pelaksanaan kegiatan pembelajaran sebaiknya guru menggunakan modialingkungan sekitaruntuk meningk atkan kemampuan eksplorasi anak, (b) Taman KanakKanak yang memiliki fasilitas dan masalah pembelajaran yang relatif sama, dapat menerapkan modialingkungan sekitar untuk meningkatkan aktivitas dan hasil belajar anak didik di TK, (c) Bagi peneliti, diharapkan hasil penelitian ini dapat dijadikan sebagai bahan rujukan dalam melaksanakan penelitian serupa.

\section{DAFTAR PUSTAKA}

Anonim. 2017. Eksplorasi-Elaborasi. [Online]. Tersedia:http://www.scribd.com/doc/31 12197/Pengertian-Eksplorasi-Elaborasi Konfirmasi, [19 Maret 2017].

Depdiknas. 2004. Pedoman Penilaian di Taman Kanak-Kanak. Jakarta: Depdiknas

Hurlock, Elizabeth. B. 1956. Perkembangan Anak. Jakarta: Erlangga.

Jamaris, Martini, 2014. Kesulitan Belajar: Perspektif, Assesmen, dan Penanggulangan. Bogor: Ghalia Indonesia

Masitoh. 2007. Strategi Pembelajaran TK. Jakarta : Universitas Terbuka.

Rachmawati \& Kurniati. 2012. Strategi Pengembangan Kreativitas pada Anak Usia Taman Kanak-Kanak. Kencana Prenada Media Group: Jakarta.

Slamet. 2003. Belajar dan Faktor-faktor yang Mempengaruhi. Jakarta, Rineka Cipta.
Sujiono, Nurani Yuliana. 2006. Metode Pengembangan Sains. Jakarta : Universitas Terbuka.

Undang-undang Nomor 20 Tahun 2003 Tentang Sistem Pendidikan Nasional Republik Indonesia.

Wonorahardjo, Surjani. 2010. Dasardasar Sains. Jakarta: Indeks Jakarta.

Yusuf, Syamsu. 2007. Upaya Meningkatkan Kemampuan Bahasa Peserta Didik. Yogyakarta: Media Grup 